\title{
Anthropomorphism as a methodological problem of animal ethics (in the memory of Sir Patrick Bateson) ${ }^{1}$
}

\author{
Petr Jemelka \& Martin Gluchman
}

\begin{abstract}
The paper aims to highlight the serious methodological issue of contemporary bioethics (especially topics on the subject of animal ethics). In the discourse on the issue of the pain and suffering of animals and in derived questions, a certain form of anthropomorphism is manifested. Ethical applications of empirical research results that are relevant to humans (or humans as an anatomically and physiologically analogous animal species) are preferred. Subsequently, these extrapolations serve as a criterion for judging the qualitative level of the capabilities of all animals. Serious ethical conclusions are drawn from this reduction.
\end{abstract}

Keywords: bioethics, anthropomorphism, animal behaviour, pain, evolution

The contemporary form of the interpretation of some results in the field of neurosciences presents "cartesian" approach through the complex participation of modern experimental research of man and animals. It is also related to the problem of pain and its perception and is unfortunately transformed even to ethical conceptions. It touches on the sphere of bioethics as well (animal ethics, ethics of medicine and nursing, etc.), but as an area of projection of human self-understanding into the interpretation of reality, it interferes even on a deeper level of ethical discourse - including ethics of scientific work, itself.

\section{Contemporary renaissance of Cartesianism}

We can define the presented issue in a way that Descartes' original (and often criticized) opinion on the status of animals ${ }^{2}$ and the conclusions derived from it, has been updated, somewhat controversially. Briefly, the more general viewpoint is the traditional belief which doesn't consider the evolution of living nature as a complex of adaptive references on various parameters meaning the search for balanced existential optimum in certain conditions. Evolution in such interpretation is understood as a "hunt", where the winner is man. Animal species are categorized in this view as the so-called 'evolutionary advanced'.

\footnotetext{
${ }^{1}$ Paul Patrick Gordon Bateson (31/03/1938 - 01/08/2017) was a key figure in ethology whose work advanced the understanding of the biological origins of behavior. His early research was on imprinting (a form of early learning in young animals). He later worked on unravelling the neurobiological mechanisms that underpin this learning. Another scientific focus was the role of play behavior in the development of the individual (physical, cognitive and social skills). Latterly, his interest turned to the evolutionary basis of development and the role of behavioral plasticity in biological evolution - see his last book 'Behavior, Development and Evolution' (Bateson, 2017). In addition to his scientific work, he made significant contributions to animal welfare and research ethics (Martin, 2017).

${ }^{2}$ Generally, according to Descartes, animals are automatically considered as working machines. They are not conscious (nor self-conscious), do not think, speak (due to any possession of tongue) and feel. The last characteristics (the absence of feeling) is controversial in traditional interpretations of Descartes' approach, which resulted from Descartes' original terminologically unclear definition (one term "cogitare" / from the French "penser" - Descartes included reasoning and sentiment). However, Descartes distinguished "cogitatio" (reasoning) and "sensus" (sentiment) and he did not deny it to animals, because he considered sentiment as a pure material (sensual) process (Cottingham, 2008, p. 164).
} 
Regarding the question of the perception of pain (or suffering) it says that we pay attention to, quantitatively, a more significant number of recent animal species. Their body structure doesn't consist of a sufficiently developed organ system, which would enable them to perceive painful impulses. From the absence of certain anatomical structures (included within the "advanced" sorts - e.g. cortex cerebri), we can deduce the evidently controversial conclusion on the limited ability of these species to include the reflection of parameters of those which (as a potentially traumatically destructive and thus more or less threatening the integrity and conservation of an organism's vital functions) cause the initialization of reflective defense mechanisms. These mechanisms are considered (analogically as in case of Descartes) as a pure reaction of the body without equivalent mental reflection on the suffering caused. In addition, there is an ethical argument of replaceability denying the individual value of organisms - all animal species are the same. ${ }^{3}$

The whole discourse is mostly related to the issue of competence to reason from the similarity of body structures to analogical sensitive - and other - competencies. ${ }^{4}$ The allowance of this analogy is usually one of the arguments used by supporters' of the idea that animals feel pain. On the other hand, objectors to this analogy refuse it as objective speculation; similarity of body structure shouldn't automatically be mistaken for functional similarity (or other similar understanding of quality). We don't want to consider behavioural arguments as analogical conclusions from the observed inner statements (behaviours). ${ }^{5}$

The Cartesian approach in ethics is significantly represented, for instance, by Peter Harrison and Peter Carruthers. The historian P. Harrison can represent the already mentioned behaviourally established refusal of analogies among us and animals. ${ }^{6}$ According to him, we shouldn't conclude on the analogical functions or similar feelings neither based on the similarities of anatomical structures of the nervous system (nor evolutionary continuity). According to Harrison, pain is a mental state requiring the ability of self-reflection and thinking (Harrison, 1991).

Peter Carruthers is even more radical, although he allows there are two types of feelings conscious and unconscious. Both types can be found in humanity, we can consider only unconscious feelings in the case of animals. Because they are not appreciated as suffering, neither are they morally relevant.

Opinions of both authors represent (at the ethical level) the stream of restored Cartesians we discussed at the beginning of this paper. Of course, both were criticized. For instance, Tom Regan claims in his well-known paper on the rights of animals: "Carruthers argues that

\footnotetext{
${ }^{3}$ This aspect can be found in the depth of xenophobic opinions, which don't respect individuality. His source is the initial inability or unwillingness to differentiate. For instance, all Chinese look the same to us regarding their appearance. It can lead us to a tendency to create typological generalizations, characterising, for instance, the members of certain ethnicities or nations (Germans are supposed to be neat, the Scottish are thrifty, etc.) We look at animals analogically - however, zoologists think that, for instance, we cannot find two zebras with the same pattern of stripes, not considering the individual differences in behaviour.

${ }^{4}$ Let's say that from the point of view of Descartes' argumentation the opossum (Didelphis marsupialis) is a mammal that is "undeveloped" or its defensive reaction consists of so-called thanatosis (the reaction typical for other animal species). In this reaction, the animal falls into the state of stiffness simulating death. In the case of the opossum, there is a possibility of serious injury to the organism, as they reflect atypically in atypical conditions for mammals (artificial breeding), as if they won't feel pain (they can, for instance, feel burns). However, in order to survive in a natural environment, they need to adjust to the environment naturally.

${ }^{5}$ This approach is certainly a proven scope, which requires further examination. We will probably admit that we cannot consider the religiousness of insect based on its manners, in case of European mantis (Mantis religiosa). On the contrary, we can easily consider the perceptive sensitiveness when suffering. And even the awareness of death is not withheld to some animals and fills them with fear.

${ }^{6}$ According to the author, we cannot consider the quality of internal states of mind and senses in terms of behaviour. Pain is apparently not perceived, but it is just a purely sensual defense mechanism.
} 
because animals are unable to use language, they are unable to think, and because they are unable to think, they are not conscious of anything ... In Carruthers's view, animal pain is 'unconscious'" (Regan, 2003, pp. 34-35). Regan consequently concludes: "Contrary to the Cartesians among us, nonhuman animals have interests; and ... the interests of animals are directly morally relevant" (Regan, 2003, p. 49).

Biologically, we can conclude the objectives towards this type of negative arguments: "acute pain is the last warning of [an] organism on an impeding danger deflecting the tissues with physical or chemical agents. Warning signals are caused in weak afferent fibers ... by stimulating activity, which enters the central nerve system (CNS) and causes a defense reaction of [the] organism accompanied with pain. Pain presents a subjective feeling of nonciceptive stimulation, therefore only a man can report on its quality and intensity. However, there is no reason to suppose that pain would exist just in terms of human living beings. All behavioral studies agree on the fact that there is a [sic] pain in [the] case of all vertebrates. Defense reactions on nonciceptive stimulations, painful for man, can be observed only in all animals including invertebrates, such as insects or worms. Therefore, only structures for nonciception, can be considered as the most primitive sensor organ significant for the purpose of life preservation and individual integrity" (Vlachová \& Viklický, 1999, p. 8).

From the mentioned approaches of both parties, it is clear that the discourse is cycled somewhere - already for some period of time. It is comparable to polemics, which caused essential theses of neo-vitalism years ago. Well, where is the similarity?

\section{Neo-vitalism as an example}

The initial objection we can have towards (neo)vitalism is related to the justification of a key thesis on the hypothetical presence of vital factors (power, energy, etc.). This factor is unable to be revealed using standard scientific methods of research into living beings. However, vitalists supposed its presence and built the whole conception of life (or the whole ontology) on this presumption. The problem of verifiability has been performed by intuitive completion of the usual empiric-rational non-ethical sources. Vitalists were not doubtful about "something" being or not being and this causes the evolution of material and living organisms. When using hopelessly rough and inadequate invasive research processes of an observed object (living organism), a non-measurable life-giving "power" slowly died forever. Traditional scientists wanted to break through the essence of life by killing to anatomize which was, according to the vitalist conception, the acting already disapproved in advance and couldn't tend towards the understanding of the phenomena of life.

Initial objections towards this argumentation construction of vitalism are its speculative character. According to critics, we shouldn't consider anything as an existing what we cannot access by exact standardized processes. Therefore we can criticize neo-vitalism as a speculation appearing from science (significant changes in physiology), which considers science and its legitimate processes as insufficient (insufficiently subtle within the methods regarding the character of the researched area).

Regarding the already mentioned issue of persisting with (or even regenerating) Cartesianism, the historical example of neo-vitalism can specifically inspire us for the requirement of critical evaluation of methodology in the scope of constructing hypotheses. We can formulate it as follows.

Through the inability of empirical methods to reveal certain qualitative (ontologically creative) characteristics of the reality of neo-vitalism reliably, he concluded its presence and significance - referring to the necessary presence of organizing factors in organized sets of reality. This approach was justly refused by critics of vitalism as an abusively speculative 
conclusion, missing empirical essentials, problematically (just subjectively) verifiable and mostly non-falsifiable.

However, we cannot raise the similar objection against the presented counter (towards the possibility of organisms to perceive painful stimulations) conclusions made by neurophysiological argumentation by using qualitative ontic hierarchization of living nature. ${ }^{7}$ The problem is that from the absence of certain anatomical structures, we can deduce merely speculative conclusions about the low quality of the perception of stimulus again. ${ }^{8}$ However, this approach arrogantly misses the undisputed fact of evolution and the success of individual life forms of such handicapped creatures. They live and successfully survive (as species and individuals) in many cases much longer (in species terminology) ${ }^{9}$ than other, so-called advanced, creatures. The reason for their evolutionary success is the fact that these organisms can efficiently (in comparison to "advanced" forms) evaluate the efficiency of the environmental factors. Their evolutionary memory (genome) fixes defense mechanisms, the activation of which is related to the adequate reflection of dangerous factors through their unpleasant activity on more or less differentiated (but functional) receptive body structures.

To conclude from the absence of anatomic-physical structure (identical or maximally similar to human) the absence of the possibility of unpleasant stimulations perception is the approach clearly speculative and reductionist. ${ }^{10}$ It is based on the hypostasis of the anthropomorphically construed vision of "the ideal type", which consequently can be considered in the forms of reflections - again compared with our experience. We again encounter verification (subjective experience and its communicability) and problems with falsification.

\section{Taxonomic reductionism and ethics of scientific work}

This warning regarding the problem within the interpretation of the stated issue can be spread using more serious methodological criticism. This considers it as a problematic approach, which, although, examines physiological processes in living organisms through modern scientific processes, however, from all the spectrum of nature (or animals) for this research, it prefers only some of the species in the long term - regardless the quantitative distribution of well-known species as well as those hypothetically appearing. There are approximately 5500 species of known mammals, there are approximately ten times more identified species of crustaceans, insects are represented by approximately one million known species. A research preference of a relatively small number of animal "prototypes" (so-called taxonomic chauvinism) is currently criticized by scientists as a crucial problem of the Ethics of Scientific Work: "Scientists who study 'unconventional' or 'unpopular' organisms often complain that their papers are rejected for publication, because they are seen as lacking general interest, whereas equally narrow studies on 'popular' or 'model organism' are accepted" (Bonet, Shine

\footnotetext{
${ }^{7}$ Undoubtedly, living nature is in a certain manner hierarchical (for instance, subcellular structures - cell - tissue - organ - organ structure - organism - cenosis - ecosystem - biosphere). However, the question is, if we can conclude the quality in terms of various "fitness" levels based on diversion. This is a rather anthropomorphist approach. We need to think of another warning on the possible risk of being subjected to seduction from anthropomorphist interpretations, where man is positioned as the evaluative criterion of evolution advancement. We cannot consider man (his sapiens form) as the top level of the evolution of living nature, because cultural evolution has influenced it in some way, which cannot be considered as the continuation of natural evolution. Read further on J. Šmajs' concept of evolution ontology.

${ }^{8}$ Let's keep the possibilities of any consideration on the form of other "subjects" aside.

${ }^{9}$ However, from the perspective of the individual, many creatures show suspicious vital success. An example is the maximum ability of regeneration (decreasing proportionately to evolution "advancement"). In relation to the specific way of reproduction (partition), let's think of the fact that unicellular organisms are potentially immortal.

${ }^{10}$ The experiments on astrobiological hypotheses consider similar problems.
} 
\& Lourdais, 2002, p. 1). And it follows: "[T]he personal interests of ornithologists and mammalogists have influenced the structure of published papers only because their study animals have dominated ecological research, and thus people interested in these organisms have come to dominate the ranks of referees and editors ..." (Bonet, Shine \& Lourdais 2002, p. 3).

The issue is not only related to the originally defined question of pain and its perception by animals, but this critical reflection affects wider ethical aspects of zoological research as well as the overall form of understanding the researched area: "Understanding the dynamic of behaviour in one taxonomic group is an important goal, but the entire field moves forward only when a series of such studies across a variety of taxa allows leaps in global understanding. ... Simply put, if we have a skewed representation of taxa in our research, then we have a skewed understanding of the world (Rosenthal, Gertler, Hamilton, Prasad \& Andrade, 2017, p. 83). Authors consequently specify the issue as it was found during a critical analysis of publications in the most significant topical magazine (Animal Behavior) that more than a half of all published articles are texts on birds and mammals, as these taxa represent only $1,5 \%$ of all animal species (Rosenthal, Gertler, Hamilton, Prasad \& Andrade, 2017, p. 85). This discovery corresponds with the above mentioned warning of privileged "interest" groups in the field of zoological (or ecological) research and the issue of publishing policy.

\section{Particular efforts to overcome the reductionism in scientific research}

Returning to the original problem of understanding pain in the case of animals, we find that even here we can find authors who strive to overcome taxonomic reductionism.

In 1991, P. Bateson offered a set of anatomical-physiological criteria for verifying experiments in the functional analogy of animal and human reception of painful stimulation (Bateson, 1991, p. 834). They are formed in short as the following criteria: “... possession of nociceptors, receptors that detect damaging stimuli on or in the body; pathways from nociceptors to the brain; brain structures analogous to the human cerebral cortex that process pain; opioid receptors and endogenous opioid substances in a nociceptive neural system; a reduction in adverse behavioral and physiological effects after administration of analgesics or painkillers; learning to avoid potentially painful stimuli and that this learning is rapid and inelastic" (Sneddon, Elwood, Adamo \& Leach, 2014, p. 201).

This paper also offers the recent form of presented definitional criteria related to the development of experimental techniques and together with extended taxonomic range of the research: "Here we list criteria that animals can be tested on to determine their potential capacity for pain. Determining whether a specific species experiences pain will typically require species-specific behavioural and physiological tests. These are based upon the mechanism to detect, react and respond to pain and have two key sets of evidence: 1) whole animal responses to noxious stimuli such as physiological change and effects of analgesic and local anaesthetics which differ from those to innocuous stimuli and 2) evidence of long-term motivational change that might include rapid learning. These criteria must be considered as a whole and not as indicators in isolation" (Sneddon, Elwood, Adamo \& Leach, 2014, p. 203).

However, this article isn't kept only within more general methodological formulations, but also offers a short summary of recent results within the category of mammals, amphibians, reptiles, fish, mollusks, some species of crustaceans and insects. We can underline one aspect here. We could easily observe that the ability of organisms to learn how to avoid painful stimulation has been classified into Bateson's mentioned set of original definition criteria. The overall actual results of recent experiments say that these abilities can be found not only in the case of birds and mammals, but even in the case of insects, fish and some mollusks (cephalopods). As it is obvious from the partial results, the proved ability of individual learning causes a serious problem for the Cartesian axiom. 
Anyway, other significant possibilities are opening up here, as they contribute to a deeper understanding - not only in the case of the psychological animal world, but even ourselves. "The experience with research into mental competencies of different animal species could lead us towards careful judgments on what is an important or necessary feature of mentality" (Müllerová, Černý \& Doležal, 2016, p. 251). In any case, we agree with this conclusion: "[F]rom an ethical and often a legal perspective, we must ensure the welfare of animals. ... $[\mathrm{H}]$ owever, even if we cannot be certain that some species experience pain, they should be treated with respect for reasons that do not hinge on whether or not they experience pain" (Sneddon, Elwood, Adamo \& Leach, 2014, p. 209).

\section{"Delictum of anthropomorphism" as an ethical challenge}

Regarding the warning on the need for respecting the welfare of animals, let us get back one more time to the essential problem of anthropomorphism.

The above mentioned experiment to solve the problems of proving the perception by applying a differentiation between pain and suffering, we are just avoiding the issue. ${ }^{11} \mathrm{We}$ even consider this process problematic because of its strong anthropomorphic aspect suffering is understood as a conscious state related to the person. The entry on Pain and Suffering in The Encyclopedia of Bioethics is defined in the same way (Post, 2004, pp. 19611969). The whole definition is focused only on the mechanisms of origin, transfer and evaluation of painful stimulation in the human body, as we defined several types of pain (acute, chronic, etc.) and special attention is paid to the mentioned form of differentiating between pain and suffering. There is no reference to the reflection of the issue in the case of other living creatures; however, there is a lot of space dedicated to theological aspects (including the relation to other encyclopedia entries such as - Palliative care, pastoral care).

$$
* * *
$$

Let us ask this question within the conclusion, whether contemporary ethics is able to overcome this scientifically supported argument with a problematic reductionist position, as we defined anthropomorphism.

Hans Jonas defined in his text from 1983 the so-called "delictum of anthropomorphism" as being responsible for subjectivity in understanding living nature and man: "Our Western understanding of philosophical tradition looks fascinated by the appearance of man itself. It attributes him with everything unique, which is rooted in the organic being as itself ... the understanding of man suffers by such a separation as well as by the understanding out-ofhuman life" (Jonas, 2005).

However, at the same time, Jonas claimed in this text that anthropomorphism is related to the fact that Darwinian versions of evolutionism, as a realization of monism, definitively terminated Cartesianism and other dualisms. This has brought the possibility of radical change of the world view: "Evolutionism weakens Descartes' construction more efficiently than any other metaphysical criticism did before. Within strong resentment over blame, teaching the animal origins of humans caused his/her dignity, it has been overseen that according to the same principle, that something from his dignity has not been returned to the kingdom of everything living" (Jonas, 2005). According to Jonas, anthropomorphism is not just a sin, which shifts the interpretation of the world in an unfavorable direction. In Jonas' phenomenologically construed argumentation, it can be the way how to reveal many of the grandiosities and the existential characteristics (freedom) traditionally assigned to man and other living creatures.

\footnotetext{
${ }^{11}$ I consider Descartes' regenerated argument of sharing (only a man can define his/her suffering, which is the evidence of his/her distinction from animals - he/she is aware of it).
} 
However, the problem is that even in Jonas' view on animals, we can find the speculative scale from "the primitive" to "the developed". Jonas also worked with the idea of larger or smaller evolutionary advancement of living creatures.

Anthropomorphism is, on one hand, a tool of Jonas' experiment for axiological rehabilitation of non-human creatures. It is applied with a good aim in mind - as searching of "superior" in "inferior". And this is his major problem - in this persisting classification of life into "superior" and "inferior", there is an internal inconsistency of text, which is undoubtedly interesting. And - as we can currently see - the already mentioned Cartesianism has not been beaten yet.

This reference to older works ${ }^{12}$ and its internal inconsistency can illustrate the opinion that contemporary ethics should strive to overcome this problematic position, which we called anthropomorphism. ${ }^{13}$ If ethics wants to testify on the set of serious bioethical questions - for instance (Bateson, 2005), it should strive not only for scientific results, but should be able to search for these results objectively (selectively or eclectically) and critically assess within its discourse. It should strive to overcome certain traditionalism in this sense and show more discourse courage. It should point to the potential sins of ethical scientific work itself, including courage.

\section{Acknowledgement}

This paper is a part of the research project - VEGA 1/0629/15 Ethics of social consequences in context of contemporary ethical theories.

Petr Jemelka is Professor of Philosophy (2012). He obtained his doctorate from Masaryk University in Brno (1998). Currently he works at the Department of Civics, Faculty of Education (Masaryk University Brno). His research focuses on the history of Czech philosophy and on bioethics (environmental ethics, animal ethics). Selected publications: Reflexe environmentální problematiky $v$ dějinách české a slovenské filosofiel Reflections on environmental issues in the history of Czech and Slovak philosophy. Prague 2016. Bioetika/Bioethics. Brno 2016. Jemelka, P., Lesňák, S., Rozemberg, A., Environmentalismus a slovenská filozofie/Environmentalism and Slovak Philosophy.Trnava 2010. O přirodé, civilizaci, historii a dalšim/About Nature, civilisation, history etc. Brno 2005.

Martin Gluchman is Assistant Professor at the Fiji National University, Department of Ethics and Governance. He did his $\mathrm{PhD}$ at the Institute of Ethics and Bioethics, Faculty of Arts, University of Prešov. He lectures the courses of Ethics, Business Ethics, and Environmental Ethics. His main field of scope is bioethics.

\section{Corresponding author:}

Petr Jemelka, Faculty of Education, Masaryk university Brno, Poříčí 31, 60200 Brno, Czech Republic

\footnotetext{
${ }^{12}$ However, the quoted Czech translation was published more than two decades after the original published piece of work. Therefore, we need to warn that this text presents an effort to define a much more closed form of questions, which H. Jonas dealt with in all his philosophical thinking. It would be very useful to compare this text with the original version of his thoughts, which Jonas produced in the 1950s. We talk about an extensive monograph, which was not published during his life and was just recently reconstructed in a critical edition (Jonas, 2016).

${ }^{13}$ More precisely - the basic reduction of preferences from the human point of view in theory made by man is obviously not possible. However, it is possible to strive to eliminate risks of reductionism and deformation in the used method as well as the designed picture of reality and conclusions related to it and value and moral challenges.
} 
Email:1178@mail.muni.cz

\section{References}

BATESON, P. (1991): Assesment of pain in animals. In: Animal Behaviour, 42(5), pp. 827839.

BATESON, P. (2017): Behaviour, Development and Evolution. Cambridge, UK: Open Book Publishers.

BATESON, P. (2005): Ethics and behavioral biology. In: Advances in the Study of Behaviour, 35, pp. 211-233.

BONNET, X., SHINE, R. \& LOURDAIS, O. (2002): Taxonomic chauvinism. In: Trends in Ecology \& Evolution, 17(1), pp. 1-3.

COTTINGHAM, R. (2008): Cartesian Reflections. Oxford: Oxford University Press.

HARRISON, P. (1991): Do Animals Feel Pain? In: Philosophy, 66(255), pp. 25-40.

JONAS, H. (2005): Evoluce a svoboda [Evolution and freedom]. In: Lidé města, 7(2) [online] [Retrieved September 17, 2017]. Available at: http://lidemesta.cz/archiv/cisla/7-20052/evoluce-a-svoboda.html.

JONAS, H. (2016): Organism and Freedom: An Essay in Philosophical Biology. In: J. O. Bechers \& F. Preußger (eds.): Berlin: Hans Jonas Zentrum. http://hans-jonas-edition.de/wpcontent/uploads/2016/10/KGA_Hans-Jonas-Kontext-Bd.-I1-Organism-and-Freedom.pdf.

MARTIN, P. (2017): Sir Patrick Bateson obituary. In: The Guardian, 14.8. 2017 [online] [Retrieved September 20, 2017]. Available at: https://www.theguardian.com/science/2017/ aug/14/sir-patrick-bateson-obituary.

MÜLLEROVÁ. H., ČERNÝ, D., DOLEŽAL, A. et al. (2016): Kapitoly o právech zvírat. „My a oni“ z pohledu filosofie, etiky, biologie a práva [Chapters on animal rights. ,we and they" form perspective of philosophy, ethics, biology and law]. Prague: Academia.

POST, S. G. (ed.) (2004): Encyclopedia of Bioethics, 3rd ed. New York: Thomson \& Macmillan.

REGAN, T. (2003): Animal Rights, Human Wrongs: An Introduction to Moral Philosophy. Lanham: Rowman \& Littlefield Publishers.

ROSENTHAL, M. F., GERTLER, M., HAMILTON, A. D., PRASAD, S. \& ANDRADE, M. C. B. (2017): Taxonomic bias in animal behaviour publications. In: Animal Behaviour, 127, pp. 83-89.

SNEDDON, L. U., ELWOOD, R. W., ADAMO, S. A. \& LEACH, M. C. (2014): Defining and assessing animal pain. In: Animal Behaviour, 94, pp. 201-212.

VLACHOVÁ, V. \& VIKLICKÝ, L. (1999): Současné trendy výzkumu buněčných mechanismů nocicepce [Current trends in nociception' cell mechanisms research]. In: Bolest, 1, pp. 8-15 [online] [Retrieved September 17, 2017]. Available at: http://www2.biomed.cas.cz/d331/cz/nocicepce_cz/Bolest1999.pdf 